Mycologia, 86(3), 1994, pp. 447-450.

(C) 1994, by The New York Botanical Garden, Bronx, NY 10458-5126

\title{
Kionochaeta pini sp. nov. and Verrucophragmia splendens gen. nov. from leaf litter in South Africa
}

P. W. Crous

Department of Plant Pathology, University of Stellenbosch, Stellenbosch 7600, South Africa

\section{J. Wingfield}

Department of Microbiology and Biochemistry, University of the Orange Free State, P.O. Box 339, Bloemfontein 9300, South Africa

\section{W. B. Kendrick}

Department of Biology, University of Waterloo, Waterloo, Ontario N2L 3G1, Canada

\begin{abstract}
A study of fungi occurring on leaf litter in South Africa revealed two new dematiaceous hyphomycetes to be present. Kionochaeta pini is newly described from pine needles and is characterized by its aseptate, fusiform conidia on conidiogenous cells situated on lateral, short branches in the middle of conidiophores. Verrucophragmia is introduced as a new genus for $V$. splendens, with simple, distoseptate, verrucose conidia attached to the conidiophore by means of a separating cell.

Key Words: foliicolous fungi, Hyphomycetes, Neesenbeckia punctoria, Pinus oocarpa, systematics
\end{abstract}

Samuels (1985) proposed that the genus Chaetopsina Rambelli should be restricted to anamorphs of Nectria with reddish-brown setose conidiophores that turn yellow in lactic acid. This view was accepted by Kirk and Sutton (1985), who further restricted Chaetopsina to species with smooth, aseptate, fusiform, holoblastic conidia with enteroblastic proliferation, and conidiogenous apparati situated terminally or along the setiform axes of the conidiophores. Kirk and Sutton $\left(\mathrm{I}^{9} 85\right)$ established the genus Kionochaeta for seven hyphomycetes with differentiated, darkly pigmented, setiform conidiophores with or without lateral branches. Fertile branches were found to be submedian, and to have conidiogenous cells in an irregular or penicillate arrangement, with proliferation either enteroblastic percurrent, or enteroblastic, leading to periclinal thickening. Conidia were described as hyaline, aseptate, smooth, ellipsoid to fusiform or clavate, rarely

Accepted for publication February 23, 1994. having a simple setula at each end. Kuthubutheen and Nawawi (r988) described two further species from decaying leaves in Malaysia.

In a study of fungi occurring on leaf litter of various plants in South Africa, a Kionochaeta species was found sporulating on laminae of pine needles. Based on its conidium and conidiophore morphology, as well as the characteristic arrangement of its conidiogenous cells, this species appears to be distinct from other known taxa in Kionochaeta and is described here as new.

Kionochaeta pini Crous, Wingfield et Kendrick, sp. nov.

FIGS. 1, 2

Coloniae effusae, luteolae, marginibus laevibus. Conidiophora differentiata, simplicia, erecta, recta vel leviter flexuosa, 10-septata, verrucosa, parietibus crassis, subulata, brunnea, ad apicem pallidiora, 120-180 $\mu \mathrm{m}$ alta, 6-9 $\mu \mathrm{m}$ lata ad basim; rami fertiles in parte media. Cellulae conidiogenae ampulliformes ad lageniformes vel cylindricae, 4-6 $\times 2.5-3 \mu \mathrm{m}$, semper in latere eodem conidiophori; collaretta apicalia indistincta. Conidiorum secessionum schizolyticum proliferatione enteroblastica, sine progressione, regione incrassata periclinali. Conidia fusiforma ad cylindrica, hyalina, laevia, aseptata, $10-12 \times 1.5-2 \mu \mathrm{m}$, in gutta exorientia.

HOlOTYPE. SOUTH AFriCA. NOrThern Natal: Kwambonambi, on laminae of dead needles of Pinus oocarpa Schiede, Jan. 1984, M. J. Wingfield (PREM 51440).

ETYMOLOGy. Pini $=$ in reference to host substrate.

Colonies on 2\% malt extract agar (MEA), effuse, pale yellow, with smooth margins. Temperature requirements for growth: minimum, 10-15 C; optimum, 25 C; maximum, 30-35 C. Conidiophores differentiated, simple, erect, straight or slightly flexuous (FIG. 1), thick-walled and verrucose, up to 10 -septate, subulate, brown, becoming paler toward the apex, 120-180 $\mu \mathrm{m}$ tall, $6-9 \mu \mathrm{m}$ wide at base; fertile region situated in middle of conidiophore. Conidiogenous cells arising on several short branches, always developing on the same side of the conidiophore, one to two per branch, ampulliform to lageniform or cylindrical, 4-6 $\times 2.5-3$ $\mu \mathrm{m}$; apical collarettes inconspicuous. Conidial secession schizolytic with enteroblastic proliferation, leading to periclinal thickening. Conidia fusiform to cylindrical (FIG. 2), hyaline, smooth, aseptate, 10-12 $\times$ $1.5-2 \mu \mathrm{m}$, accumulating in a mucous droplet.

A dematiaceous hyphomycete has been found recently on leaves of Neesenbeckia punctoria (Vahl) Leyns 


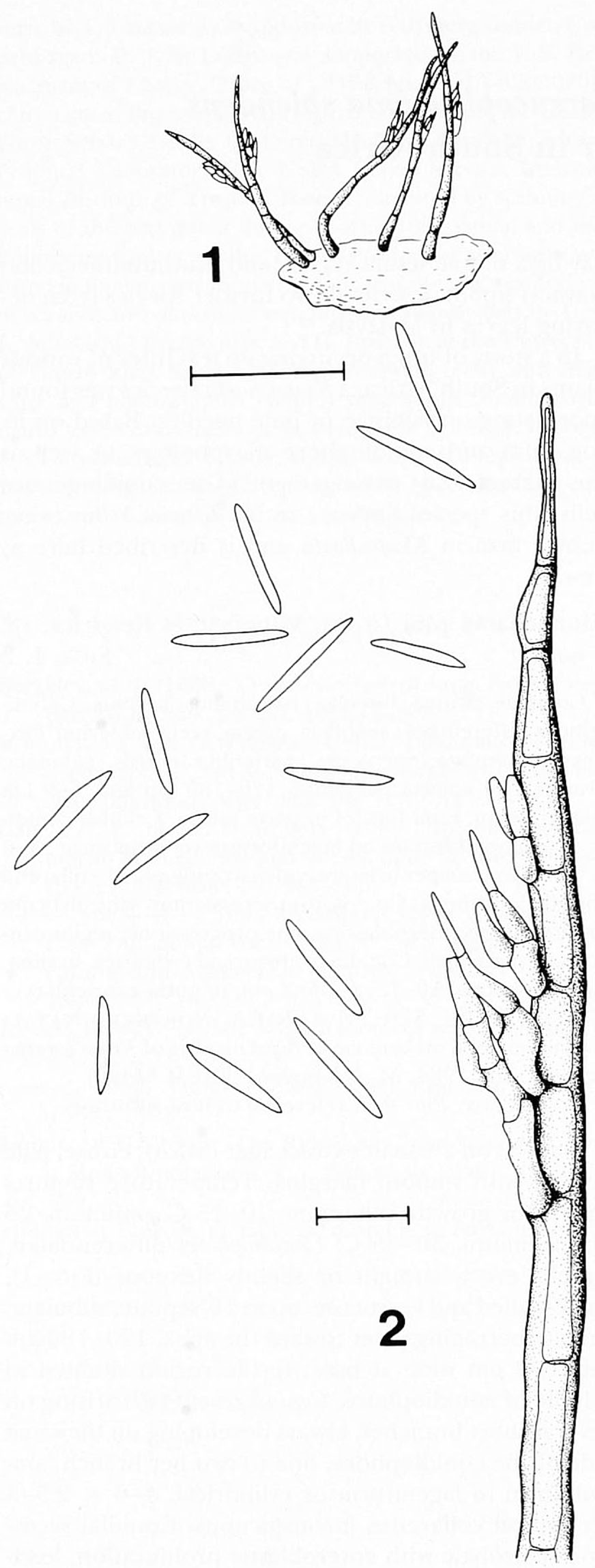

Figs. 1, 2. Conidiophores and conidia of Kionochaeta pini. 1. Conidiophores in situ, bar $=120 \mu \mathrm{m}$. 2. Conidiogenous apparatus and fusiform to cylindrical conidia, bar $=10 \mu \mathrm{m}$.
(Cyperaceae), occurring in the South African fynbos biome (Takhtajan, 1969), and is described herein. Conidiophores of this fungus are differentiated, regenerated enteroblastically, and are simple or branched at the apices, with septate conidiogenous regions. Phragmoconidia are brown, verrucose and distoseptate. Conidia also remain firmly attached to conidiogenous loci after maturity, and frequently germinate in situ, producing unusual, verrucose germ tubes, which form hyphal thickenings resembling chlamydospores. The most significant morphological feature of this fungus is its thickened, protuberant conidiogenous loci, which are also found in genera such as Asperisporium Maublanc, Eriocercospora Deighton, Sirosporium Bubák \& Serebrianikow, Stenella Sydow and Verrucispora Shaw \& Alcorn. It can be distinguished from Eriocercospora by having verrucose, beaked conidia and immersed mycelium, and from Asperisporium by not having closely packed sporodochia with short conidiophores. The generic concepts of Verrucispora, Sirosporium and Stenella overlap and are somewhat unclear. The fungus from Neesenbeckia does not have the well developed substomatal stroma characteristic of Verrucispora, and the conidia are distinct from those in all three genera (Ellis, I97I) in being simple, distoseptate, frequently attached to the conidiogenous cells by means of a separating cell, and germinating in situ. Because our fungus cannot suitably be accommodated in any of those genera discussed above, a new genus Verrucophragmia gen. nov. is proposed for it.

Verrucophragmia Crous, Wingfield et Kendrick, gen. nov.

Mycelium intramaticale et extramaticale, cellulis brunneis, cylindricis, laevibus, parietibus crassis. Conidiophora differentiata, solitaria, erecta, non-ramosa vel ramosa apicalia, recta vel flexuosa, parietibus crassis, brunneis, enteroblastico semel vel bis extensis, laevia, sed super proliferationem, subinde verrucosa. Cellulae conidiogenae integratae, polyblasticae, sympodiales, brunneae, parietibus crassis; conidiogenarum regio septata. Conidia apicalia, veteria in situ remanentia, sicca, solitaria, verrucosa, brunnea, ad apice pallescentia, obclavati, distoseptata, secessio schizolytico.

ETYMology. Verrucosa and phragmia refer to the verrucose phragmospores.

TYPE SPECIES. Verrucophragmia splendens Crous, Wingfield et Kendrick, sp. nov.

Mycelium intramatrical and extramatrical, cells brown, cylindrical, smooth, thick-walled. Conidiophores differentiated, solitary, erect, simple or branched above, straight or slightly flexuous, thickwalled, multiseptate, with a rounded base, dark brown, becoming brown towards the apex, sometimes extending once or twice enteroblastically, mostly smooth, but occasionally verrucose just above proliferation. 


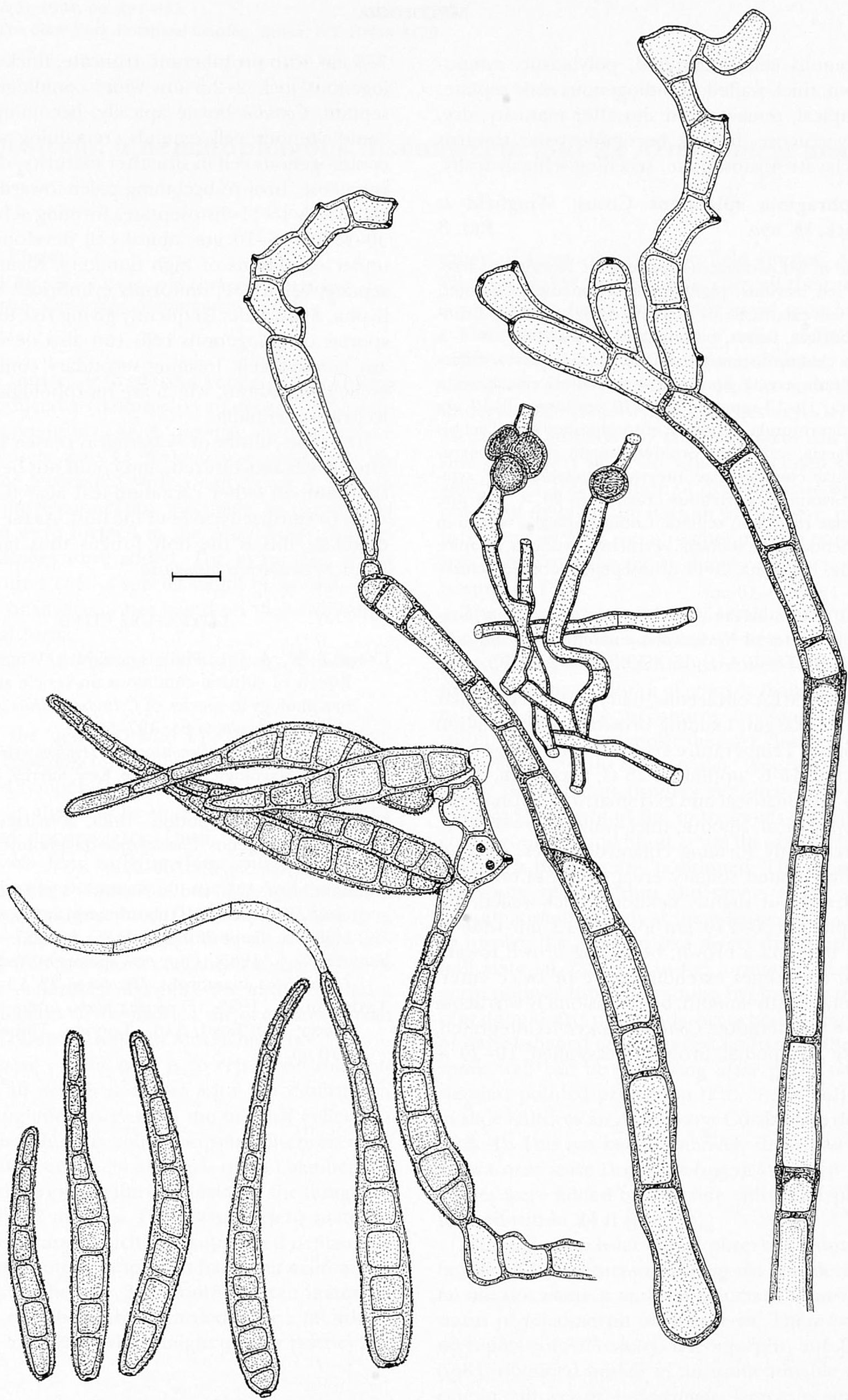

FIG. 3. Regenerating conidiophores with thickened conidiogenous loci, mycelium and conidia of Verrucophragmia splendens in situ, bar $=10 \mu \mathrm{m}$. 
Conidiogenous cells integrated, polyblastic, sympodial, brown, thick-walled; conidiogenous zone septate. Conidia apical, remaining in situ after maturity, dry, solitary, verrucose, brown, becoming paler towards apex, obclavate, distoseptate, seceding schizolytically.

Verrucophragmia splendens Crous, Wingfield et Kendrick, sp. nov.

FIG. 3

Coloniae in MEA olivaceae, puberulae, marginibus irregularibus sed laevibus, pigmentum brunneum exudantes. Mycelium intramatricale et extramatricale, cellulare brunneae, cylindricae, laeves, parietatibus crassis 20-40 × 4-5 $\mu \mathrm{m}$, saepe chlamydosporas formans. Conidiophora differentiata solitaria, erecta, non-ramosa vel ramosa apicali, recta vel flexuosa, 10-13-septata, 180-270 $\mu \mathrm{m}$ longa, 9-12 $\mu \mathrm{m}$ lata ad basim rotunda, brunnea, enteroblastico semel vel bis extensis, laevia, sed super proliferationem subinde verrucosa. Cellulae conidiogenae integratae, polyblasticae, sympodiales, brunneae, parietibus crassis, $10-20 \times 7-8 \mu \mathrm{m}$; conidiogenae regio non septata. Conidia apicala, veteria in situ remanentia, sicca, solitaria, verrucosa, brunnea, ad apice pallescentia, obclavata, 3-11-distoseptata, secessio schizolytico, $50-150 \times 6-10 \mu \mathrm{m}$.

HOLOTYPE. SOUTH AFRICA. Western CAPE: Grabouw, on leaf litter of Neesenbeckia punctoria, Jan. 1986, M. J. Wingfield (PREM 51441); ISOTYPE (IMI 356540).

Colonies on MEA olivaceous, hairy, with an irregular but smooth margin, exuding brownish pigmentation into medium. Temperature requirements for growth: minimum, 5-10 C; optimum, $25 \mathrm{C}$; maximum, $35 \mathrm{C}$. Mycelium intramatrical and extramatrical, hyphal cells brown, cylindrical, smooth, thick-walled, $20-40 \times 4-$ $5 \mu \mathrm{m}$, frequently forming chlamydospores. Conidiophores differentiated, solitary, erect, simple or branched above, straight or slightly flexuous, thick-walled, 10to 13-septate, $180-270 \mu \mathrm{m}$ long, 9-12 $\mu \mathrm{m}$ wide at rounded base, dark brown, becoming brown toward the apex, sometimes extending once or twice enteroblastically, mostly smooth, but occasionally verrucose just above proliferation. Conidiogenous cells integrated, polyblastic, sympodial, brown, thick-walled, 10-20 $\times$
7-8 $\mu \mathrm{m}$, with protuberant, truncate, thickened conidiogenous loci, 2-2.5 $\mu \mathrm{m}$ wide; conidiogenous zone septate. Conidia borne apically, becoming lateral as conidiogenous cell extends, remaining attached to conidiogenous cell in situ after maturity, dry, solitary, verrucose, brown, becoming paler towards apex, obclavate, 3- to 11-distoseptate, forming schizolytically, $50-150 \times 6-10 \mu \mathrm{m}$; apical cell developing further under conditions of high humidity, forming a long, septate, verrucose, uniformly cylindrical, light brown hypha, $3 \mu \mathrm{m}$ wide, frequently giving rise to chlamydospores; conidiogenous cells can also develop out of any conidial cell, forming secondary conidia (microcyclic conidiation), which are morphologically similar to primary conidia.

The type culture of $V$. splendens ceased to sporulate after it was subcultured, and could not be induced to sporulate on either carnation-leaf agar (Crous et al., 1992) or sterilized leaves of the host. As far as we could establish, this is the only fungus thus far described from Neesenbeckia punctoria.

\section{LITERATURE CITED}

Crous, P. W., A. J. L. Phillips, and M. J. Wingfield. 1992. Effects of cultural conditions on vesicle and conidium morphology in species of Cylindrocladium and Cylindrocladiella. Mycologia 84: 497-504.

Ellis, M. B. 1971. Dematiaceous Hyphomycetes. Commonwealth Mycological Institute, Kew, Surrey, United Kingdom. 608 pp.

Kirk, P. M., and B. C. Sutton. 1985. A reassessment of the anamorph genus Chaetopsina (Hyphomycetes). Trans. Brit. Mycol. Soc. 85: 709-718.

Kuthubutheen, A. J., and A. Nawawi. 1988. Two new species of Kionochaeta (Hyphomycetes) and K. ramifera from Malaysia. Trans. Brit. Mycol. Soc. 90: 437-444.

Samuels, G. J. 1985. Four new species of Nectria and their Chaetopsina anamorphs. Mycotaxon 22: 13-32.

Takhtajan, A. 1969. Flowering plants origin and dispersal. Oliver and Boyd, Ltd., London, United Kingdom. $310 \mathrm{pp}$. 